\title{
Plant communities as drivers of soil respiration: pathways, mechanisms, and significance for global change
}

\author{
D. B. Metcalfe ${ }^{1}$, R. A. Fisher ${ }^{2}$, and D. A. Wardle ${ }^{1}$ \\ ${ }^{1}$ Department of Forest Ecology and Management, Swedish University of Agricultural Sciences, Umeå, Sweden \\ ${ }^{2}$ Climate and Global Dynamics Division, National Center for Atmospheric Research, Boulder, Colorado, USA
}

Received: 7 February 2011 - Published in Biogeosciences Discuss.: 3 March 2011

Revised: 18 July 2011 - Accepted: 18 July 2011 - Published: 3 August 2011

\begin{abstract}
Understanding the impacts of plant community characteristics on soil carbon dioxide efflux $(R)$ is a key prerequisite for accurate prediction of the future carbon (C) balance of terrestrial ecosystems under climate change. However, developing a mechanistic understanding of the determinants of $R$ is complicated by the presence of multiple different sources of respiratory $C$ within soil - such as soil microbes, plant roots and their mycorrhizal symbionts - each with their distinct dynamics and drivers. In this review, we synthesize relevant information from a wide spectrum of sources to evaluate the current state of knowledge about plant community effects on $R$, examine how this information is incorporated into global climate models, and highlight priorities for future research. Despite often large variation amongst studies and methods, several general trends emerge.

Mechanisms whereby plants affect $R$ may be grouped into effects on belowground $\mathrm{C}$ allocation, aboveground litter properties and microclimate. Within vegetation types, the amount of $\mathrm{C}$ diverted belowground, and hence $R$, may be controlled mainly by the rate of photosynthetic $\mathrm{C}$ uptake, while amongst vegetation types this should be more dependent upon the specific $\mathrm{C}$ allocation strategies of the plant life form. We make the case that plant community composition, rather than diversity, is usually the dominant control on $R$ in natural systems. Individual species impacts on $R$ may be largest where the species accounts for most of the biomass in the ecosystem, has very distinct traits to the rest of the community and/or modulates the occurrence of major natural disturbances. We show that climate vegetation models incorporate a number of pathways whereby plants can affect $R$, but that simplifications regarding allocation schemes and drivers of litter decomposition may limit model accuracy. We also suggest that under a warmer future climate, many plant
\end{abstract}

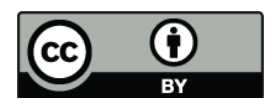

Correspondence to: D. B. Metcalfe (daniel.metcalfe@slu.se) communities may shift towards dominance by fast growing plants which produce large quantities of nutrient rich litter. Where this community shift occurs, it could drive an increase in $R$ beyond that expected from direct climate impacts on soil microbial activity alone.

We identify key gaps in knowledge and recommend them as priorities for future work. These include the patterns of photosynthate partitioning amongst belowground components, ecosystem level effects of individual plant traits, and the importance of trophic interactions and species invasions or extinctions for ecosystem processes. A final, overarching challenge is how to link these observations and drivers across spatio-temporal scales to predict regional or global changes in $R$ over long time periods. A more unified approach to understanding $R$, which integrates information about plant traits and community dynamics, will be essential for better understanding, simulating and predicting patterns of $R$ across terrestrial ecosystems and its role within the earthclimate system.

\section{Introduction}

Understanding and predicting the impacts of global climate change on terrestrial ecosystems is one of the main research challenges of the 21 st century. Progress towards this goal has focused on modeling the impacts of a wide array of climate change agents on key ecosystem level processes such as carbon (C) (Cramer et al., 2001; Friedlingstein et al., 2006) and nutrient cycling (Gruber and Galloway, 2008). However, these large scale processes are mediated via the plant community present within the system, which is also likely to change in response to climate shifts (Neilson et al., 2005). As such, many of the effects of climate change on ecosystem processes may be manifested through shifts in plant community properties. A large body of literature has developed, particularly over the last two decades, on the effects of plant

Published by Copernicus Publications on behalf of the European Geosciences Union. 
community composition and diversity on a range of ecosystem processes (Hooper and Vitousek, 1998; Tylianakis et al., 2008; de Deyn et al., 2008). Understanding the process of ecosystem $\mathrm{C}$ sequestration is particularly important, because this information underpins government strategies aimed at limiting green house gas emissions in line with their $\mathrm{Ky}$ oto protocol commitments. Soil carbon dioxide $\left(\mathrm{CO}_{2}\right)$ efflux $(R)$ is the largest single source of $\mathrm{CO}_{2}$ from terrestrial ecosystems globally (Raich and Potter, 1995), and is about ten times greater than anthropogenic fossil fuel combustion (Boden et al., 2009). It is therefore a key determinant of ecosystem $\mathrm{C}$ sequestration, atmospheric $\mathrm{CO}_{2}$ concentrations and climate change. Yet relatively little is known about interactions between $R$ and plant community properties such as species composition and diversity.

Most studies which have directly investigated the effects of plant community diversity and composition upon $R$ have been conducted in grasslands (Craine et al., 2001; de Boeck et al., 2007; Dias et al., 2010) and have yielded notably different results in terms of the relative importance of species diversity versus composition for patterns of $R$. In common with all research on $R$, making useful inferences from these studies is hampered by the fact that $R$ is a complex signal that integrates myriad interactions amongst heterogeneous populations of microbes, fungi and plants and the physical structure of the soil matrix (Subke et al., 2006; Kuzyakov, 2006). Sources of $R$ fall broadly into two distinct categories with fundamentally different drivers and behavior: those sources which utilize old $\mathrm{C}$ (microbial respiration of organic matter) and those which largely depend upon recent plant photosynthate (respiration of live roots, mycorrhizae and some microbes subsisting on root exudates). The first group is relatively amenable to controlled experimentation, responds predictably to changes in temperature and moisture, and has thus been readily incorporated into models simulating $R$ (Davidson and Janssens, 2006). However, the sources in the second category are partly decoupled from local soil conditions because they are driven by patterns of plant $\mathrm{C}$ assimilation, production and allocation (Högberg et al., 2001; Janssens et al., 2001) which are more difficult to measure and represent within existing model frameworks. This remains a major impediment to understanding and predicting $R$ in natural ecosystems, because belowground $\mathrm{C}$ allocation from plants may contribute over $50 \%$ of total $R$, shows substantial seasonal variation, and is responsive to a variety of drivers (Litton and Giardina, 2008).

A wide range of studies have been conducted which, whilst not directly investigating the link between plant species and $R$, provide valuable insights into potential mechanisms. The purpose of this review is to draw together these studies, so as to identify overarching patterns of how plant species influence $R$, as well as the underlying mechanisms responsible for these effects. We focus on the following three distinct but interlinked topics which are each relevant to understanding how plant community properties affect $R$ :
(1) plant traits (Wardle et al., 2004; Cornwell et al., 2008; de Deyn et al., 2008), (2) plant invasions and range expansions (Peltzer et al., 2010), and (3) plant diversity (Hättenschwiler et al., 2005; Hooper et al., 2005). Finally, given the likelihood of future large scale shifts in the distribution, composition and diversity of plant communities driven by climate change (Neilson et al., 2005), we discuss the contrasting approaches taken by major models to simulate species effects on ecosystem C cycling (Cramer et al., 2001; Friedlingstein et al., 2006; Ostle et al., 2009; Reu et al., 2010). In doing so, we highlight potentially important ecological processes currently missing from the model frameworks, evaluate approaches to integrating field data into effective model representations of the processes in question, and suggest priorities for future research.

\section{Plant traits and soil respiration}

It has long been recognized that a wide variety of plant anatomical, physiological and chemical traits co-vary together, reflecting fundamental evolutionary tradeoffs between alternative life history strategies (e.g., Grime et al., 1974; Wright et al., 2004). At one end of the spectrum are plants with a suite of traits maximizing rapid resource acquisition that are favored in fertile or productive environments (Fig. 1). At the other end are plants with traits prioritizing resource conservation which dominate in infertile and or unproductive environments (Fig. 1). Over the last decade, many studies have focused on linking this spectrum of traits to a range of ecosystem level processes and properties (e.g., Chapin, 2003; Diaz et al., 2004; de Deyn et al., 2008). With respect to $R$, the plant traits of importance may be broadly grouped into traits controlling (1) the amount and chemical composition of organic matter deposited onto the soil surface, (2) the amount and destination of plant $\mathrm{C}$ allocated belowground, and (3) the physical properties of the soil and near surface atmosphere (Fig. 2). We now discuss each of these in turn.

\subsection{Effects on aboveground litter quantity and quality}

Faster growing plants generally produce more litter, richer in nitrogen $(\mathrm{N})$ but poorer in $\mathrm{C}$ rich structural compounds, which is more easily broken down by soil microbes and hence respired as $R$ (Fig. 1). Slow growing plants not only acquire less $\mathrm{C}$ via photosynthesis but release less over time in recalcitrant litter forms that suppress decomposition and $R$ (Fig. 1). Further, the breakdown products of some recalcitrant compounds form complexes with amino acids and enzymes which inhibit decomposition (Hättenschwiler and Vitousek, 2000). Plant production is generally highest in warm, wet climates (Fig. 3c), which are the same abiotic conditions that also promote $R$. However, there still exists very little data on several potentially large components of plant 
production - notably belowground components and losses to herbivory - which could potentially alter our current picture of patterns in production, which is mainly shaped by observations from aboveground growth alone. Across different forest biomes, there is clear variation in the mean proportion of $R$ which could be derived from canopy litter fall C, increasing from around 0.15 in boreal forests to $\sim 0.33$ in tropical forests (Chen et al., 2010). Global syntheses show that there is a consistent positive relationship between $R$ and different measures of plant production (Raich and Schlesinger, 1992). While some of this relationship may be correlative rather than causal in nature, it is likely that existing plant community level variation in productivity amplifies the differences in $R$ amongst biomes that would occur simply as a result of abiotic variation. At finer spatial scales, the link between plant productivity and $R$ often weakens or breaks down entirely (e.g., Jurik et al., 1991; Ruess, 1996) probably because other factors become more important, as we discuss later. Over this century, rising $\mathrm{CO}_{2}$ levels and $\mathrm{N}$ deposition are predicted to enhance plant productivity (Holland et al., 1997; Rustad et al., 2001), both via direct fertilization effects and indirectly through gradual shifts in plant community composition towards greater dominance of faster growing species or those with rapid turnover. This rise in plant productivity could conceivably drive a greater increase in $R$ than would be predicted by most current climate models, which primarily consider direct impacts of climate change on soil microbial activity

Physical and chemical properties of plant litter vary greatly both among and within plant communities and may serve as powerful drivers of $R$ by determining litter mass loss rates (Fig. 3e). Cornwell et al. (2008) analyzed results from 14 studies spanning contrasting climatic zones which each measured litter decomposition of at least 20 species at a local scale. These revealed consistent correlations between decomposition and leaf nutrient content, thickness and lignin content, which underlay large differences in decomposition rates between different plant functional and taxonomic groups. For example, decomposition of litter from bryophytes and ferns was significantly slower than that from eudicot plants, decomposition of woody deciduous plant litter was much faster than that from evergreen species, and decomposition of herbaceous forb litter was faster than that from graminoids. Yet despite these differences, no clear current biome level differences in litter decomposition emerged. The observed 18.4 fold variability in decomposition rates among species within sites (Cornwell et al., 2008) reinforces other syntheses highlighting the very high local scale variation in leaf traits amongst coexisting species (e.g., Hättenschwiler et al., 2008; Richardson et al., 2008). By comparison, decomposition of standardized litter material across continental or global climatic gradients displayed only a 5 fold variation, (Berg et al., 1993; Parton et al., 2007). However, other processes also show strong variation with climate and soil types which influence the rate of incorporation of

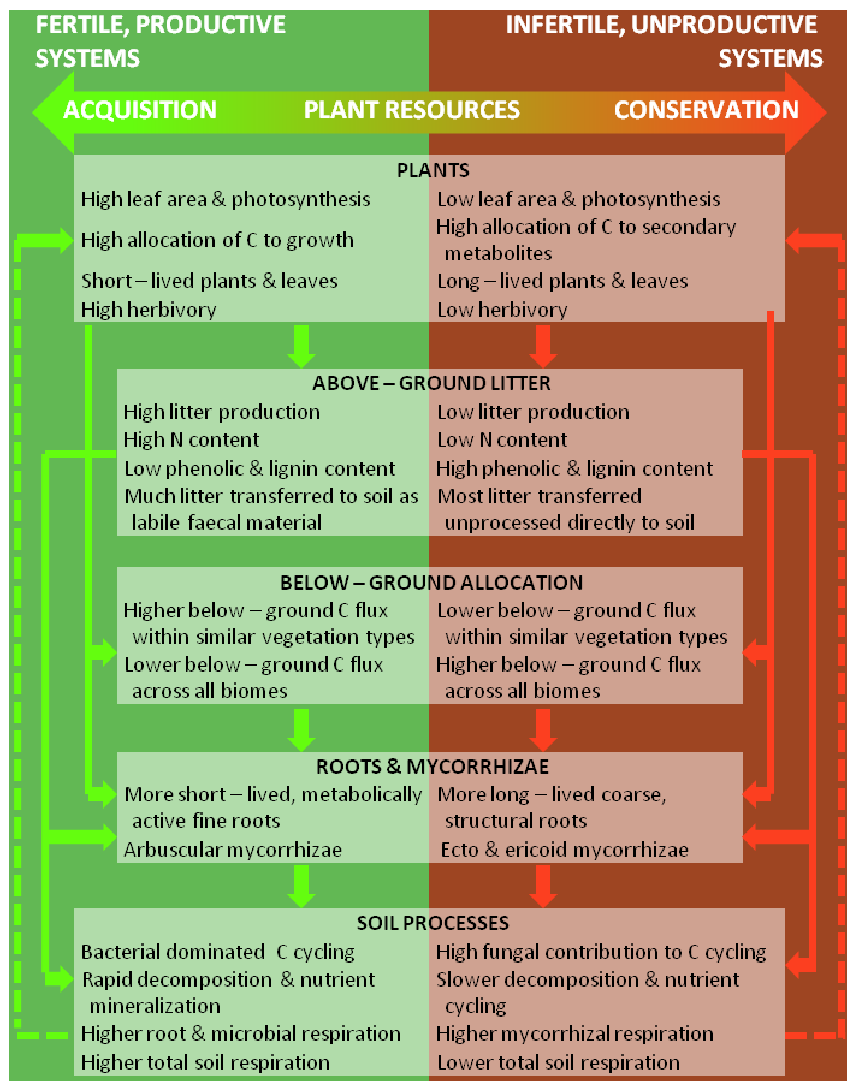

Fig. 1. Conceptual framework of linkages amongst plant traits and key plant and soil processes that affect soil $\mathrm{CO}_{2}$ efflux in contrasting terrestrial ecosystems. Note that these are generalizations with many exceptions. Modified from Wardle et al. (2004).

litter material into soils. For example, herbivores and soil macrofauna are often more abundant in warm and/or fertile sites (Coley and Barone, 1996) and fertile sites are usually also dominated by faster growing plants maximizing resource acquisition (McNaughton et al., 1989). Herbivores can potentially inhibit or promote $R$ via a large number of mechanisms (Bardgett and Wardle, 2003). The most consistent single effect is excretion of plant material in labile $\mathrm{C}$ and $\mathrm{N}$ forms which facilitates rapid microbial respiration and would therefore likely cause higher rates of $R$. Macrofauna could further contribute to this process by physically mixing and breaking apart litter (González and Seastedt, 2001), which enhances the accessibility of organic matter for microbes and fungi. Therefore, direct climate effects on decomposition rates, while significant, will likely be exceeded by indirect effects manifested through plant community composition and the structure and dynamics of the community food web. 


\subsection{Effects on plant allocation belowground}

In forest ecosystems, $\mathrm{C}$ input from aboveground canopy litter is rarely more than $40 \%$ of $R$ (Chen et al., 2010), so the remaining majority of $R$ must be derived from other sources. The principal alternative route for $\mathrm{C}$ is plant photosynthate channeled directly belowground via phloem transport, which constitutes around $40 \%$ of GPP in forested systems (Litton et al., 2007). This total belowground $\mathrm{C}$ flux (TBCF) is governed in the first instance by the total amount of $\mathrm{C}$ acquired by photosynthesis (gross primary productivity or GPP), which is likely to be higher for species that prioritize resource acquisition, and which have both more leaf area and higher photosynthetic rates per unit leaf area (Fig. 1). Plants also vary in the proportion of GPP diverted to TBCF, which may be highest for those species with a suite of traits which together maximize resource retention (Fig. 1). These species tend to prevail in arid or infertile environments where there are potentially considerable benefits in allocating more $\mathrm{C}$ belowground to enhance uptake of soil resources (Cannell and Dewar, 1994) though this would also depend on other factors, such as herbivory pressure (e.g., Lerdau and Gershenzon, 1997; Fine et al., 1994). Most support for this hypothesis comes from data on biomass stocks rather than fluxes, which shows that there is usually a greater proportion of total plant biomass located belowground under infertile or dry conditions (e.g., Vitousek and Sanford, 1986; Vogt et al., 1995; Waring and Schlesinger, 1985; Brown and Lugo, 1982; Keyes and Grier, 1981; Nadelhoffer et al., 1985; Heilmeier et al., 1997) although a comprehensive review found no clear trend across different forested ecosystems or climatic conditions (Cairns et al., 1997). By comparison, there are relatively few field studies which have measured both GPP and TBCF fluxes, so this idea has yet to be extensively tested in the field, but preliminary analyses indicate that the proportion of GPP diverted to TBCF tends to be higher (i.e., $>0.5$ ) in forests in arid environments (Litton et al., 2007). Most detailed vegetation $\mathrm{C}$ budgets have focused on forests and have examined impacts of different environmental factors at the level of the whole ecosystem rather than at the species or functional group level. Results suggest that GPP and the proportion of GPP invested in TBCF often show opposing responses to shifts in site fertility and water availability, with consistent trends among different tree species (Litton et al., 2007; Litton and Giardina, 2008). However, across forests worldwide, TBCF as a proportion of GPP shows only a relatively slight decrease from around 0.6 to 0.4 over a six fold increase in GPP (Litton et al., 2007). It therefore seems that over broad scales across structurally similar, undisturbed vegetation types, TBCF will likely be driven mainly by differences in GPP rather than the proportion of GPP partitioned to TBCF (Figs. 2b, d, 3). How well this generalization applies to vegetation types other than forests has not been extensively tested. Changes in plant community composition within a particular vegetation type (or one dominated by a

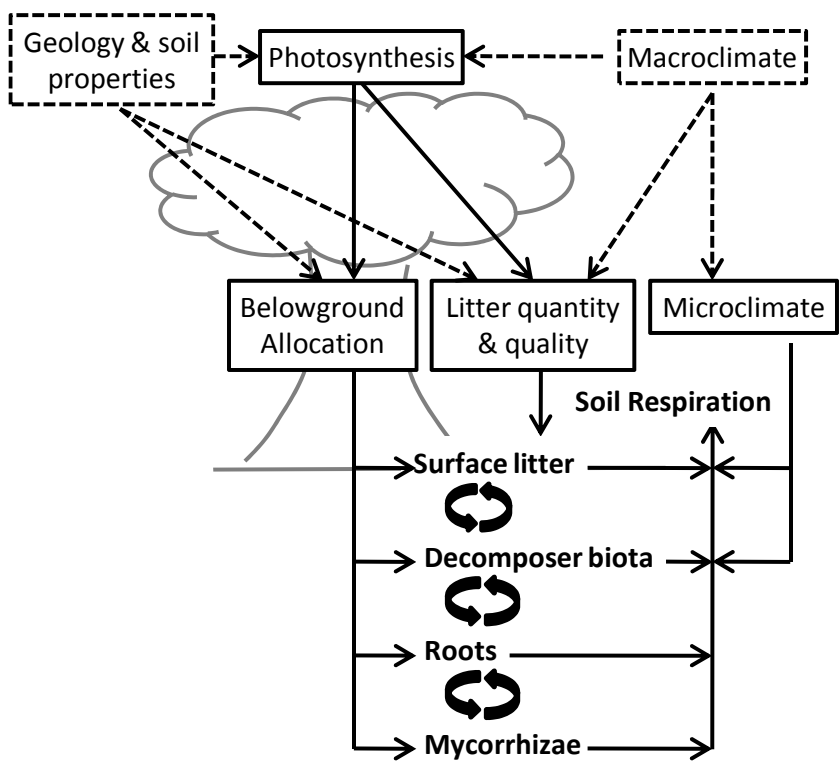

Fig. 2. Key determinants of soil respiration. Dashed boxes and arrows indicate abiotic, indirect factors and their pathways of influence on direct, plant mediated impacts denoted with solid boxes and arrows. Bold text outside of boxes represents the principal contributors to soil respiration.

particular plant life form) that involve an increase in the relative abundance of species towards more photosynthetically active plants adapted for rapid resource acquisition should therefore lead to an increase in GPP, TBCF and thus $R$. Possible examples of this situation include increased liana abundance across the Amazon rainforest (Phillips et al., 2002), and encroachment of temperate hardwoods into the southern limits of evergreen pine dominated forests in Northern $\mathrm{Eu}-$ rope (Sykes and Prentice, 1996).

In contrast, if environmental changes are sufficient to cause shifts in the abundance of fundamentally different plant life forms, differences in the proportion of GPP diverted to TBCF amongst these life forms will potentially play a much greater role in determining $R$. Consequences of these shifts for $R$ will be more difficult to predict, and will depend largely upon species or group specific anatomy, physiology and allocation strategy. For example, trees tend to construct more coarse structural roots to enhance plant stability. Coarser roots are usually longer lived with low respiratory rates, are better physically defended from herbivores, and decompose more slowly once dead (in the order of years to decades), which would collectively serve to suppress root contributions to $R$. In contrast, grasses and forbs often produce finer roots with higher respiratory rates, and of higher chemical quality which turnover within weeks to years (Gill and Jackson, 2000; Comas et al., 2002), resulting in root litter which is preferentially targeted by herbivores and decomposes relatively rapidly (Silver and Miya, 2001; Bardgett and Wardle, 2003). This could help to explain why $R$ 


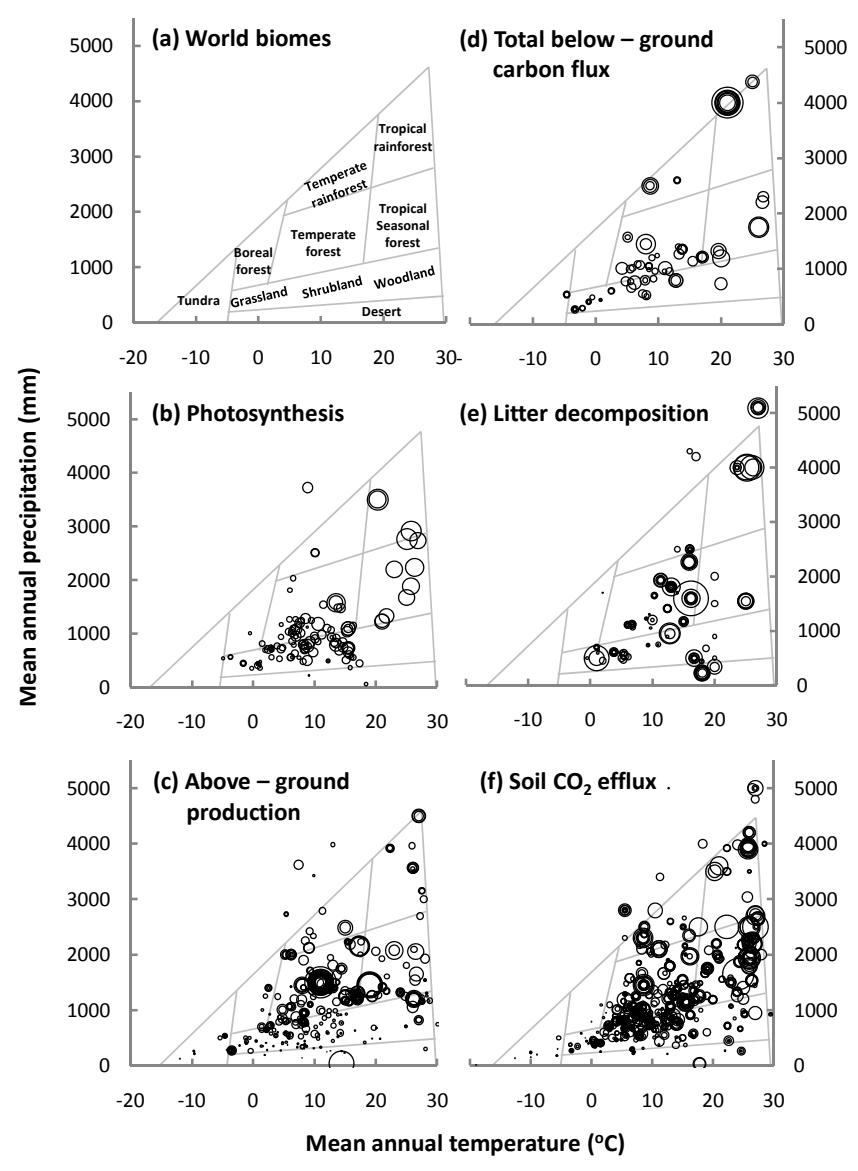

Fig. 3. Distribution of plant biomes ${ }^{1}$ (a), annual gross primary productivity $^{2}$ (b), annual aboveground plant productivity ${ }^{3}$ (c), total annual belowground carbon flux ${ }^{4}$ (d), litter decomposition rate ${ }^{5}$ (e) and soil $\mathrm{CO}_{2}$ efflux ${ }^{6}$ (f) in relation to mean annual site air temperature and rainfall. Note that a number of factors (e.g., vegetation and/or soil type) co-vary with global temperature and moisture gradients. Belowground carbon flux is presented only for forest ecosystems, the other variables span all ecosystems for which data are available. Soil $\mathrm{CO}_{2}$ efflux data is presented only for unmodified, natural systems. The diameter of the circles denotes the magnitude of the values. Data sources: ${ }^{1}$ Whittaker (1975); ${ }^{2}$ Luyssaert et al. (2007); ${ }^{3}$ Ohnson et al. (2001); ${ }^{4}$ Litton and Giardina (2008); ${ }^{5}$ Zhang et al. (2008); ${ }^{6}$ Bond-Lamberty (2010).

in grasslands is generally higher than in forests under comparable climates and soils (Raich and Tufekcioglu, 2000), despite often having similar or lower aboveground productivity. Potential examples of this, more substantial, plant community transformation include predicted replacement of large expanses of Amazon rainforest with savannah as the region becomes drier (Zelazowski et al., 2011), or large reductions in moss and lichen cover and increasing tree and shrub cover in arctic tundra associated with rising temperatures (Chapin et al., 1995; Cornelissen et al., 2001). Ascertaining impacts of climate driven community shifts on $R$ will be further complicated by species specific tissue respiration responses to temperature change and, for each species, the degree to which respiration acclimates over time under the new climate regime (Atkin et al., 2008). Thus far, we have focused on factors determining the amount of TBCF (Fig. 4). However, an important source of plant species specific influence over soil $\mathrm{C}$ cycling arises from differences in how TBCF is partitioned amongst roots, mycorrhizae and soil exudates (de Deyn et al., 2008). Amongst forest systems globally, the estimated proportion of TBCF used for root growth increases from 0.26 to 0.53 as mean annual site temperature rises from -5 to $30^{\circ} \mathrm{C}$ (Litton and Giardina, 2008). Root structure and chemistry vary substantially amongst plant functional groups, as discussed above. Recent evidence from an arctic tundra community suggests that basic species root traits, such as $\mathrm{C}, \mathrm{N}$ and lignin concentration and dry matter content, were closely correlated with the same traits in stems and leaves (Freschet et al., 2010). Further work in other systems is required to examine the extent to which aboveground traits can be used to predict belowground plant characteristics. Similarly to decomposition patterns of aboveground litter, root decomposition rates vary widely primarily due to tissue chemistry, with climate playing only a secondary role (Silver and Miya, 2001). Root herbivores proliferate in warm, fertile soils where they selectively consume high quality root material, most commonly associated with fast growing, resource-acquisition-prioritizing plants, which is then excreted in relatively labile $\mathrm{C}$ forms easily utilized by soil microbes (Bardgett and Wardle, 2003). Therefore, plant functional differences in root properties may drive shifts in soil food webs that can also impact upon $R$.

Litton and Giardina (2008) found that only $\sim 25 \%$ of TBCF was diverted to root growth in cold climate forests compared to around $50 \%$ in warmer climates. This implies that the remainder of TBCF, presumably dedicated to mycorrhizae and/or root exudates, is generally higher in coldadapted forests compared to those in warmer climates. We note that this pattern could be related to a number of factors (e.g., vegetation, soil type) that co-vary with temperature at the global scale. Such a pattern is consistent with independent, experimental observations that the proportion of TBCF diverted to mycorrhizae tends to be higher in slower growing plants on infertile soil (Hobbie, 2006). However, additional field data, particularly from the tropics, is required to provide a more robust assessment of global patterns amongst different plant communities in the fraction of TBCF used by mycorrhizae.

In comparison with fine roots, mycorrhizal hyphae have shorter life spans (Godbold et al., 2006), are more dependent on recent plant photosynthate (Högberg et al., 2001, 2010) and contain more recalcitrant structural compounds that inhibit decomposition (Langley and Hungate, 2003). In addition, mycorrhizal colonization affects losses of $\mathrm{C}$ from the root system via respiration, decomposition and consumption (Langley and Hungate, 2003; Hughes et al., 2008). Therefore, the abundance and types of mycorrhizae occurring in 


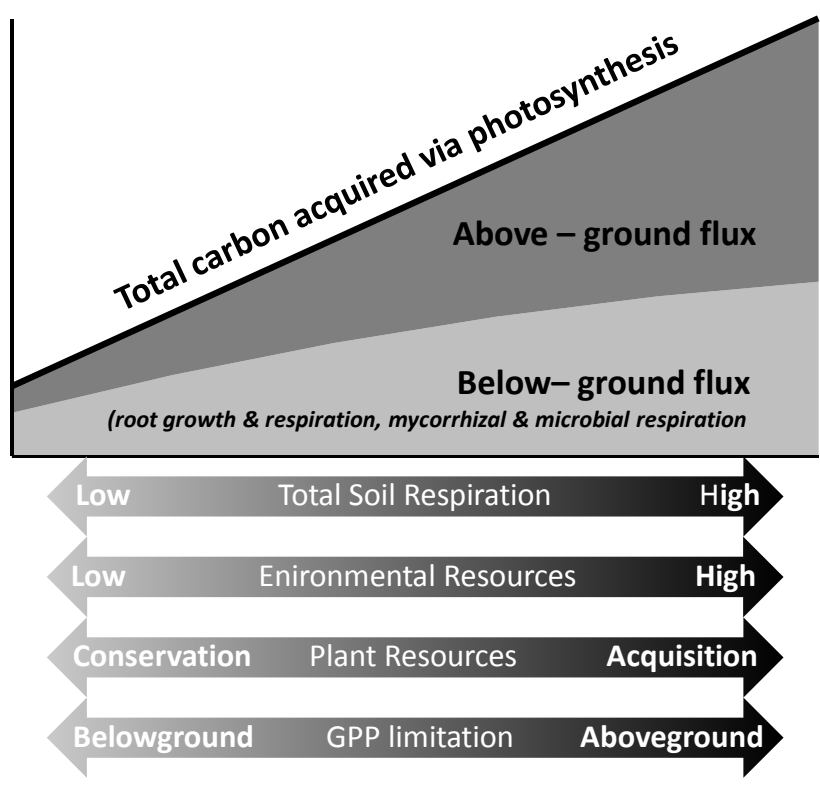

Fig. 4. Hypothesized relationships between GPP partitioning and soil respiration, abiotic factors, plant functional type and limitations to photosynthesis. Modified from Litton and Giardina (2008).

an ecosystem have a potentially large influence on $R$. In a survey of 83 British plants of known mycorrhizal affiliation, plant species forming associations with arbuscular mycorrhizae were shown to have traits linked with the maximization of resource acquisition (Fig. 1), such as high seedling growth rates, elevated leaf nutrient concentrations and high tissue decomposability (Cornelissen et al., 2001). By comparison, plants forming ericoid and ectomycorrhizal associations tended to have traits associated with resource retention. Thus plant and mycorrhizal traits may act in concert to regulate soil biogeochemistry. For example, in environments where mineral $\mathrm{N}$ is in short supply (e.g., boreal forests and tundra) mycorrhizae may enable plants to compete more effectively with soil microbes and saprotrophic fungi for a wide range of soil nutrients, including complex organic compounds (Persson and Näsholm, 2001), and often suppress decomposition (and thus nutrient supply for other plants) through a variety of mechanisms (Bending et al., 2003; Langley and Hungate, 2003). Such plants often also possess litter traits characteristic of a resource conservation strategy (Fig. 1) which serve to further reduce rates of soil $\mathrm{C}$ cycling and hence $R$. Thus, plant mycorrhizal associations may serve to reinforce and amplify existing differences in $R$ driven by environmental factors and other plant traits.

Root exudates are a diverse group of compounds which interact in numerous ways with plant roots, soil microbes and macrofauna, and can represent a substantial proportion of belowground $\mathrm{C}$ allocation for herbaceous plant species (Inderjit and Weston, 2003). In some cases, root exudates may promote microbial breakdown of previously inaccessible soil C compounds and thereby further boost $R$ (Kuzyakov et al., 2006). However, the functional significance of many exudates is still poorly understood and some have been found to contain toxins which suppress microbial activity (Inderjit and Weston, 2003). The amount and composition of exudates appear to vary greatly amongst species and growth strategies (Grayston et al., 1996) but further research is required before any general pattern between plant functional type and exudate production can be identified with sufficient confidence to predict the consequences for $R$.

\subsection{Effects on microclimate and soil structure}

Plant traits can have a diverse range of effects on soil properties and habitat microclimate (Chapin, 2003). Our aim here is not to provide an exhaustive list, but to highlight the most widespread and important effects with respect to $R$. In particular, vegetation effects on soil temperature and moisture are important, because these factors are key physical drivers of microbial activity and hence $R$ (Davidson and Janssens, 2006). Dense vegetation canopies are often dominated by light demanding, resource-acquisition-prioritizing plants. Such canopies often reduce ground level radiation and soil evaporation rates, which maintain greater soil moisture levels and lower temperatures that both, in turn, potentially affect $R$ (Pierson and Wight, 1991; Breshears et al., 1997, 1998). Canopy and soil albedo can vary substantially amongst plant communities, with important consequences for soil properties (Gao et al., 2005). Interactive effects of vegetation and albedo can be particularly powerful in boreal systems where snowpack depth and the duration of winter snow cover are key determinants of $R$ (Brooks et al., 2004). Another important, but underappreciated, effect of plants lies in their potential to influence the spatial distribution and timing of $R$ by affecting the speed with which $\mathrm{CO}_{2}$ diffuses from the soil. For example, dense canopies can impede air circulation (particularly at night), causing sub-canopy accumulation of $\mathrm{CO}_{2}$ to concentrations up to $90 \%$ more than in the above canopy atmosphere (de Araújo et al., 2008). At a broad scale this may not matter since this $\mathrm{CO}_{2}$ will likely emerge somewhere else or at some later time, but for interpreting spatially patchy, instantaneous records of $R$ it has important consequences. The patterns described above operate at relatively broad scales as the integrated product of a plant community. Effects of an individual species on microclimate will become significant where the species is the dominant constituent of the community. The wide diversity of possible mechanisms, whereby plant traits could influence soil and vegetation structure, means that no consistent, integrated effect on $R$ can be ascribed to a specific plant functional type. Instead, effects will be highly context dependant, resulting from interactions between particular combinations of plants, their associated biota, and the physical environment. 


\section{Plant invasions and range expansions}

Shifts in plant species distribution via invasions and range expansions are currently widespread and likely to increase further due to climate changes (Neilson et al., 2005). Such shifts can serve as natural experiments which provide valuable insights into the myriad effects of individual plant species on ecosystem structure and function. A growing number of studies have shown that even single plant species can drive major changes in ecosystem wide C cycling (Bradley et al., 2006; Litton et al., 2008; Peltzer et al., 2010). In a survey of 94 experimental studies, invaded ecosystems on average had $83 \%$ higher productivity and $117 \%$ faster litter decomposition rates (Liao et al., 2008), often driven in part by consistent trait differences between invading species and native species. While there is little direct information on the effects of plant invasions on $R$, these shifts in production and decomposition suggest that invaded ecosystems would on average have higher $R$. Two contrasting hypotheses, which are relevant to understanding and predicting average effects of species invasions on ecosystem processes, have each gathered some support from experiments and field observations. The first, the "mass ratio" hypothesis, asserts that species which account for a high proportion of the total ecosystem biomass should exert a greater influence on ecosystem processes, such as $R$, than uncommon, low biomass species (Grime et al., 1998). One example of this is the invasion of conifers throughout treeless ecosystems in the Southern Hemisphere (Richardson and Rejánek, 2004). The second and opposing hypothesis predicts that even locally rare, low biomass species may have significant impacts on ecosystem processes when they possess key traits that differ substantially from the surrounding community. For example, compared to native dominant trees in Hawaii, the invading $\mathrm{N}$ fixer Myrica faya has foliage with a higher photosynthetic rate, and produces litter with a lower C to $\mathrm{N}$ ratio which decomposes faster (Matson, 1990), all of which might be expected to promote $R$. In a New Zealand shrub dominated floodplain, Peltzer et al. (2009) found that the removal of several exotic species with distinct life history and leaf traits, but comprising less than $3 \%$ of total plant biomass, caused significant reductions in surface litter, soil C and basal respiration, and major shifts in soil microbial and macrofaunal populations.

Some plant species with low biomass and broadly similar traits to other species in the community can nevertheless regulate ecosystem processes like $R$ by controlling the frequency and or severity of large scale disturbance events such as fires (Mack and D'Antonio, 1998). For example, invasion of exotic grass species through many tree dominated systems has caused a large rise in fire frequency through changes in ground litter flammability (D'Antonio and Vitousek, 1992). Conversely, encroachment of trees into grass or shrub dominated systems may reduce surface fuel loads thereby suppressing fire (Braithwaite et al., 1989; Doren and Whiteaker, 1990). Fire affects soil C cycling in a large num- ber of ways over different time scales (Certini, 2005), which makes it very difficult to reliably predict the net effect of these changes in fire regime on $R$. The existence of complex, context dependant interactions between species and disturbance agents and other factors, means that the effects of individual species on $R$, while potentially large, cannot be confidently predicted from general principles but should be examined on a case by case basis.

\section{Plant species diversity}

With biodiversity of many groups of organisms declining a thousand times faster now than at any time in the fossil record (Millenium Assessment, 2005), attention has turned to the effects of this loss upon key ecosystem processes (see syntheses by Hooper et al., 2005; Balvanera et al., 2006; Cardinale et al., 2006). A large number of experimental studies have used synthetic species assemblages varying in species richness to show that some ecosystem processes, notably productivity, increase with richness (Hooper et al., 2005; Marquard et al., 2009), but reach an asymptote at richness levels that are lower than most natural systems. If this is the case, then a decline in species richness in low diversity systems may lead to decreased $R$ as productivity and hence organic litter input to soil declines. However, such studies may have limited relevance for understanding natural communities in which species composition and species losses are determined by environmental pressures, species recruitment, extinction, dispersal patterns and traits of the constituent species (Huston, 1997; Grime, 1998). For this reason, experimental removal of key species or functional groups from natural systems may provide a better picture of how ecosystem processes, such as $R$, may be influenced by nonrandom species losses from plant communities (Diaz et al., 2003). Further, there is still relatively little direct evidence from natural gradients for the sort of strong biodiversity-function relationships frequently predicted from experimental studies (Levine and D'Antonio, 1999; Mittelbach et al., 2001). Indeed, the largest and clearest terrestrial diversity gradient on the planet - increasing from the poles to the tropics (Gaston 2000; Hillebrand 2004) is not clearly related to latitudinal variation in aboveground productivity or $R$ (Fig. 3c, f; Huston and Wolverton, 2009). The lack of any strong change in $R$ over such a large and spatially consistent increase in plant diversity towards the tropics indicates that large-scale patterns of $R$ in natural systems are probably overwhelmingly dominated by factors other than diversity.

A smaller, but rapidly growing, number of studies have specifically examined plant diversity impacts on soil processes. Results indicate that key facets of soil functioning, such as decomposition, microbial nutrient cycling, and $R$, are often more dependent upon the functional traits of the dominant plant species than diversity per se (Wardle et al., 1999; Bardgett and Shine, 1999; Hector et al., 2000; Johnson et 
al., 2008). Where a link between diversity and $R$ has been found, this has often been mediated via the effect of diversity on plant production (e.g., Zak et al., 2003; Craine et al., 2001; Dias et al., 2010). Other studies highlight the importance of particular species or functional groups, rather than diversity, in determining ecosystem level patterns of $R$ (de Boeck et al., 2007; Johnson et al., 2008; Ward et al., 2009). For example, Johnson et al. (2008) found consistent differences in $R$ amongst established grassland mesocosms driven by functional group rather than diversity. As such, forb dominated mesocosms had higher $R$ while sedge dominated communities with relatively high biomass had low $R$. The lack of any clear link between $R$ and plant biomass, either above or belowground, indicates that $R$ in these systems may be controlled by other functional group specific mechanisms (e.g., soil water availability, mycorrhizal association).

Plant removal experiments further illustrate the potential importance and complexity of the interactions between community composition, nonrandom species loss and $R$ in natural systems. For example, in a removal experiment along a boreal forest succession, the presence of tree roots or the shrub Vaccinnium vitis-idaea were both linked to increased litter decomposition and soil microbial respiration, and therefore potentially also with $R$, but only at the early stages of vegetation succession (Wardle and Zackrisson, 2005). In contrast, plots with and without removal of V. myrtillus had similar levels of soil microbial respiration across the whole gradient. In a similar plant community, removal of ericoid shrubs more than doubled both ecosystem respiration $(R$ and above ground plant respiration) and photosynthesis, and increased the rate of photosynthate transfer through the plant and soil (Ward et al., 2010). Isotopic labeling showed that this effect was largely driven by the graminoids that dominated in ericoid free plots, which showed relatively high innate rates of $\mathrm{CO}_{2}$ uptake and turnover, and were suppressed by the presence of ericoid shrubs. Effects of species can persist long after they have disappeared from the community: 40 years after selective logging of a single forest tree species in New Zealand, consistent and significant differences in soil chemical and biological properties were observed around the tree stumps compared with the surrounding forest (Wardle et al., 2008).

Given that the majority of plant biomass is returned to the soil as litter, plant diversity effects on decomposition and hence $R$ may often be manifested through mixing of litter from different species. Respiration rates of single species litter are usually well correlated with species specific litter chemistry and structure (Aerts and de Caluwe, 1997). However, litter mixing studies frequently reveal different patterns of respiration for the mix, as a whole, compared to that expected from the respiration rates of each species in isolation (Gartner and Cardon, 2004; Hättenschwiler et al., 2005). Among and even within studies, a range of effects of litter mixing on respiration rates have been reported, ranging from strong negative "antagonistic" to strong positive "synergistic" effects depending on species (Gartner and Cardon, 2004) and environmental context (Jonsson and Wardle, 2008). There is little information about the mechanisms underpinning litter mixing effects on decomposition and respiration, but the most likely explanations involve effects of nutrients, soluble carbon and secondary metabolites from some litters on others, as well as alteration of decomposer trophic links and microhabitats (Hättenschwiler et al., 2005). Given the prevalence of contrasting respiratory responses among mixtures with identical species number but different composition (Gartner and Cardon, 2004), it appears that species or functional group specific litter qualities, rather than the number of species in the litter mix, are the most important determinants of litter respiration and hence $R$. Therefore, the overall message emerging from the literature on plant diversity effects upon productivity, belowground functioning and litter mixing is that plant community composition is usually the key driver of $R$ in natural systems, with diversity playing a secondary role, and then only under certain circumstances.

\section{Towards model integration of species effects}

Simulation models are essential for integrating multiple sources of ecological information, often gathered over small spatio-temporal scales and unevenly distributed across biomes, to derive regional or global estimates of key ecological processes over long time periods. Several recent syntheses of outputs from C cycle models (CCM's) provide key insights into the causes and consequences for inter-model discrepancies, and highlight important areas for future research (Cramer et al., 2001; Friedlingstein et al., 2006; Ostle et al., 2009). In all models, plant community processes have a wide range of effects on the global $\mathrm{C}$ cycle, often via their effect on $R$. In the remainder of this section, we review the status of CCM's and assess their ability to represent the previously discussed impacts of plant community on $R$. We focus on the following sample of widely used CCM's, all of which remain in a state of continuous development: TRIFFID (Cox, 2001), LPJ-GUESS (Smith et al., 2001), ED (Moorcroft et al., 2001), LPJ (Sitch et al., 2003), CTEM (Arora, 2003), sDGVM (Woodward and Lomas, 2004), ORCHIDEE (Krinner et al., 2005), CLM-CN (Thornton et al., 2007), SEIBDGVM (Sato et al., 2007), aDGVM (Schieter and Higgins, 2009), and O-CN (Zaehle and Friend, 2010).

\subsection{Modeling plant trait effects}

In all vegetation models, litter production is controlled by plant productivity, so that the first order relationship between production and $R$ is simulated by default. However, influences of plant type on litter quality are more variable amongst models. Plant litter traits, such as $\mathrm{C}$ to $\mathrm{N}$ ratios and tissue specific decomposition rates, vary with plant type in some CCM's (e.g., O-CN, CLM-CN, sDGVM and CTEM). 
In other cases, litter decomposition is simulated as a function of abiotic conditions and tissue type (LPJ, LPJ-GUESS, SEIB-DGVM, aDGVM), while some do not even explicitly simulate a litter pool independent of the soil carbon pool (TRIFFID). Further, no models simulate interactions between abiotic drivers and populations of aboveground or soil fauna that may be, in some cases, important drivers of soil $\mathrm{C}$ cycling. Models that exclude the potential for links between litter type and decomposition, or interactions that involve different trophic groups within the community, may underestimate the alterations in $R$ generated by climate changes.

Vegetation models also vary in how they determine the fate of $\mathrm{C}$ allocated to roots and exudates. As such, some models use a single allometric relationship between the quantities of $\mathrm{C}$ partitioned aboveground and belowground (ED, SEIBDGVM), but the majority of models now vary the proportion of GPP diverted belowground according to estimated soil water or nutrient limitations (e.g., O-CN, LPJ , LPJGUESS, aDGVM, sDGVM, CLM-CN, and ORCHIDEE). Shifts in root production will impact on $R$ partly via altered supply of root litter. Only O-CN and LPJ distinguish between above and belowground dead organic matter pools, whereas all other models treat these pools together. The impact of this simplification is unclear, but in the LPJ model, decomposition of aboveground litter is driven by air temperature, and belowground litter by soil temperature, which might have an important effect in ecosystems with very large diurnal air temperature fluctuations. The majority of vegetation models calculate plant tissue respiration based on an exponential temperature response curve. However, this function is more appropriate for instantaneous temperature responses, and does not take into account the potential for differential acclimation of respiration amongst plant functional groups to longer term temperature variations. Acclimation equations should be simple to implement in the majority of CCM's (e.g., Atkin et al., 2008), and would provide a better simulation of this widely observed phenomenon and the consequences for $R$. However, their implementation could be problematic in the absence of a better understanding of photosynthetic temperature acclimation amongst species, which may produce impacts that negate those of respiratory acclimation (Sage and Kubien, 2007). Given that soil organisms and food webs are responsive to climate change (Tylianakis et al., 2008) there is also considerable scope for acclimation of soil biota to altered temperature regimes, but the specific consequences for $R$ remain largely unknown and these interactions are not currently captured by CCM's

To simulate the impact of plants on microclimate, and hence potentially $R$, all models represent differences in albedo amongst vegetation types, and simulate the consequences for near surface air temperatures. Other interactions that are typically resolved within CCM's include: (1) the impact of vegetation on radiation interception and albedo, and thus snowpack depth, which enhances soil insulation and increases winter $R$ where snow is thicker; (2) the extraction of water by roots from deep soil layers, which increases the latent heat fraction and reduces overall surface air temperatures in seasonally dry environments; and (3) the impact of canopy shading on soil surface evaporation, which maintains wetter surface soils and thus stimulates $R$. Processes that are typically not resolved, which might affect $R$, include the redistribution of soil moisture by deep root systems (but see Harper et al., 2010), the impact of plant canopies, ground litter and water logging on the circulation of $\mathrm{CO}_{2}$ within soil and the near surface atmosphere, and litter moisture content. In all models, the moisture availability constraint on litter decomposition is that of the soil moisture of the top layer of the soil, and not of the litter layer itself. Given that the litter layer often contains much of the labile $\mathrm{C}$ in the soil, and may experience very different moisture regimes to the soil layers below, this simplification could confound attempts to accurately simulate $R$.

\subsection{Modeling effects of plant invasions and diversity}

The effects of individual invasive plant species on ecosystem processes, such as $R$, cannot usually be captured by generic CCM's parameterized at the scale of whole biomes. This is partly due to deficiencies in model structure, but also attributable to inadequate information about the factors determining invasion success and the mechanisms underlying observed ecosystem level impacts of most invasive plant species. The basis for the dominance of a particular invasive plant in its new range may not be related to easily identifiable ecosystem or species properties that could feasibly be represented within CCM's. However, inclusion of already widespread species, whose large impact on $R$ can be demonstrated and for which the mechanisms of dominance are understood, should be considered. For example, many invasive species that become abundant are symbiotic $\mathrm{N}$ fixers and inclusion of $\mathrm{N}$ fixers as a separate plant functional type is now possible in some vegetation models (Fisher et al., 2010). Thus, the potential exists to simulate plant invasion and range shifts for some broad, easily identifiable plant types and their impacts on $R$ via alterations in soil conditions and plant productivity.

The existing structure of vegetation models, with less than 20 plant functional types used to represent all plant species globally (Ostle et al., 2009), is inappropriate for simulating the full range of possible interactions between plant diversity and $R$. The most straightforward apparent solution to this issue is to include a greater variety of plant types in vegetation models. However, in most simulations that include a link between plant growth and plant success, simply increasing the number of available plant types does not necessarily increase the simulated diversity, as exclusion of slow growing plants by fast growing plants is a likely outcome of the competitive process simulated. Clark et al. (2007) argue that within species variation in plant properties can explain and alleviate this problem, and that the standard approach of using mean 
species properties to drive CCM's is flawed, because coexistence is greatly facilitated by within species (or plant type) genetic and environmentally modulated heterogeneity. One promising framework is provided by the JeDi model (Reu et al., 2010) that generates a theoretical plant community whose traits vary along twelve functional trade-off gradients. A coupled plant physiology model selects a subset of plant physiological strategies that survive under a given set of climate conditions. This approach has met with some success at predicting global patterns of plant diversity, although it has yet to be coupled to a model that simulates the potential for coexistence of the theoretically plausible plant types. Once this is achieved, then a model based exploration of the interactions between plant diversity and emergent ecosystem properties, such as $R$, might become a plausible goal.

\section{Conclusions}

Plant communities influence $R$ via many mechanisms over a range of spatial and temporal scales. The most obvious and direct mechanism is plant control of the quantity and quality of organic inputs to the soil. There is often a clear link between plant production and $R$ (Raich and Schlesinger, 1992). Therefore, shifts in $R$ could be amplified beyond those expected solely from climate-change-induced effects on soil microbial activity, in those systems for which plant productivity may rise due to increasing temperatures and $\mathrm{N}$ availability (Holland et al., 1997; Rustad et al., 2001). Further, plant species traits determine the quality of resource input to the soil both within and among communities, which may influence $R$ (de Deyn et al., 2008). Abiotic drivers of global change may also accelerate decomposition rates of organic litter and hence $R$, but this effect will likely be complicated by changes in litter traits associated with shifts in community composition and possibly species diversity. The impacts of species shifts on $R$ may be particularly large where they involve species that account for most plant biomass in the system, as well as subordinate species that have very different traits (e.g., litter chemistry, $\mathrm{N}$ fixation ability) to the rest of the community. Large impacts can also occur when particular species mediate the frequency and severity of large scale disturbance events, such as fire or insect attacks.

In addition, plant effects on $R$ can operate via changes in the amount of photosynthetic $\mathrm{C}$ channeled belowground. There is evidence from forests that the total quantity of $\mathrm{C}$ fixed via photosynthesis, rather than the pattern of partitioning of this photosynthate, is the dominant control upon the amount of $\mathrm{C}$ diverted belowground within vegetation types (Fig. 4, Litton et al., 2007), but this has yet to be broadly verified for non-forested vegetation. Across ecosystems of contrasting vegetation type, or within ecosystems where fundamental shifts in dominant plant life forms occur over time, species or functional-group specific differences in the proportion of photosynthate allocated belowground will play a greater role in explaining patterns of $R$. There is preliminary evidence that cold-climate forests may expend a greater proportion of belowground $\mathrm{C}$ on mycorrhizae and/or exudates rather than on roots, when compared with forests in warmer climates (Litton and Giardina, 2008), but further field studies are required to test this. Finally, a diverse range of potentially very important plant impacts on $R$ operate via effects upon soil surface temperature and moisture levels, and other aspects of microclimate.

Climate vegetation models take a variety of approaches to simulating differences amongst plant functional types in terms of litter decomposition, belowground $\mathrm{C}$ flux, and microclimate alteration. These mechanisms provide a range of model pathways through which plants may impact upon $R$. Key areas for potential improvement include allocation schemes, regulation of litter decomposition and the extent and speed of respiratory acclimation to temperature increases. A cohesive framework for prediction of plant impacts on $R$ is urgently required to inform model simulations of climate-vegetation interactions and design effective mitigation strategies. We outline the following areas as critical gaps in ongoing efforts to construct such a framework:

- The fate of belowground carbon. A key uncertainty, in determining the effects of shifts in belowground $\mathrm{C}$ flux on $R$, is how this $\mathrm{C}$ is partitioned amongst roots, fungi and microbes. Each compartment has distinct sensitivities, $\mathrm{C}$ turnover rates and trophic interactions with soil biota that can affect the amount of $\mathrm{C}$ released from soil as $R$ (Subke et al., 2006; Kuzyakov, 2006). Combination of whole plant isotopic labeling with techniques that isolate $\mathrm{C}$ in specific soil fractions (e.g., Högberg et al., 2010) will make significant advances in this field.

- Linking plant traits to ecosystem effects. The wide diversity of plant function and form can, to some extent, be simplified along fundamental trait axes that describe contrasting life history strategies (Grime et al., 1974; Wright et al., 2004). Improved knowledge of how these traits simultaneously determine plant responses to environmental change and plant effects upon ecosystem processes (Diaz et al., 2004; Suding et al., 2008) will increase our ability to link climate changes with shifts in $R$ mediated via plant community characteristics.

- Biotic interactions. Idiosyncratic ecological outcomes, which are particularly challenging to predict (and, when necessary, to prevent or mitigate), often result from complex interactions of organisms with each other and with their environment (e.g., by controlling fire disturbance frequency, Mack and D'Antonio, 1998). Identifying when, where, and why these nonlinear feedbacks occur will be critical for successfully modeling and managing $\mathrm{CO}_{2}$ emissions from $R$ in terrestrial ecosystems. 
- Species gains and losses. For a variety of aesthetic and economic reasons, there is considerable interest in the wider ecosystem effects of species extinctions and invasions. While there have been important advances in developing general principles about how plant species invasions may affect ecosystem processes relevant to $R$ (e.g., the "mass ratio hypothesis", Grime et al., 1998), our understanding of how species losses in real ecosystems affect these processes remains more limited. Further application of promising approaches such as species removal experiments and species specific isotopic labeling will help to tease apart the myriad factors determining the effects of individual species or functional groups on $R$.

- Integrating across scales. Soil C models are mainly driven by soil temperature and moisture. These factors are often excellent predictors of $R$ over short temporal scales and under particular conditions (Davidson, 2010). However, over larger spatiotemporal scales, plant activity and other factors may become increasingly important. Thus, regional or global scale modeling of $R$ over long time scales may be particularly dependent upon an accurate representation of seasonal variation in plant $\mathrm{C}$ allocation amongst different functional groups.

Acknowledgements. DAW was supported by the Wallenberg Scholars award. We acknowledge all authors of the original versions of the figures presented in this paper. In particular, we thank authors contributing data for Fig. 3. For GPP data in Fig. 3b, we thank all site investigators, their funding agencies, the various regional flux networks and the Fluxnet project, whose support is essential for obtaining the measurements without which the type of integrated analyses conducted in this review would not be possible.

Edited by: M. Khomik

\section{References}

Aerts, R. and de Caluwe, H.: Initial litter respiration as indicator for long-term leaf litter decomposition of Carex species, Oikos, 80, 353-361, 1997.

Arora, V. K. and Boer, G. J.: A representation of variable root distribution in dynamic vegetation models, Earth Interact., 7, 1-19, 2003.

Atkin, O. K., Atkinson, L. J., Fisher, R. A., Campbell, C. D., Zaragoza-Castell, J., Pitchford, J. W., Woodward, F. I., and Hurry, V.: Globally heterogeneous impacts of thermal acclimation by plant respiration, Global Change Biol., 14, 2709-2726, 2008.

Balvanera, P., Pfisterer, A. B., Buchmann, N., He, J.-S., Nakashizuka, T., Raffaelli, D., and Schmid, B.: Quantifying the evidence for biodiversity effects on ecosystem functioning and services, Ecol. Lett., 9, 1146-1156, 2006.
Bardgett, R. D. and Shine, A.: Linkages between plant litter diversity, soil microbial biomass and ecosystem function in temperate grasslands, Soil Biol. Biochem., 31, 317-321, 1999.

Bardgett, R. D. and Wardle, D. A.: Herbivore mediated linkages between aboveground and belowground communities, Ecology, 84, 2258-2268, 2003.

Bending, G. D.: Litter decomposition, ectomycorrhizal roots and the "Gadgil" effect, New Phytol., 158, 228-229, 2003.

Berg, B., Berg, M. P., Bottner, P., Box, E., Breymeyer, A., Ca de Anta, R., Couteaux, M., Escudero, A., Gallardo, A., and Kratz, W.: Litter mass-loss rates in pine forests of Europe and Eastern United States - some relationships with climate and litter quality, Biogeochemistry, 20, 127-159, 1993.

Boden, T. A., Marland, G., and Andres, R. J.: Global, regional, and national fossil-fuel $\mathrm{CO}_{2}$ emissions, Carbon Dioxide Information Analysis Center, Oak Ridge National Laboratory, available at: http://cdiac.ornl.gov/trends/emis/overview2006.html, last access: 5 January 2011, 2009.

Bond-Lamberty, B. and Thomson, A.: A global database of soil respiration data, Biogeosciences, 7, 1915-1926, doi:10.5194/bg7-1915-2010, 2010.

Bradley, B. A., Houghton, R. A., Mustard, J. F., and Hamburg, S. P.: Invasive grass reduces aboveground carbon stocks in shrublands of the Western US, Global Change Biol., 12, 1815-1822, 2006.

Braithwaite, R. W., Lonsdale, W. M., and Estbergs, J. A.: Alien vegetation and native biota in tropical Australia: the impact of Mimosa pigra, Biol. Conserv., 48, 189-210, 1989.

Breshears, D. D., Rich, P. M., Barnes, F. J., and Campbell, K.: Overstory-imposed heterogeneity in solar radiation and soil moisture in a semiarid woodland, Ecol. Appl., 7, 1201-1215, 1997.

Breshears, D. D., Nyhan, J. W., Heil, C. E., and Wilcox, B. P.: Effects of woody plants on microclimate in a semiarid woodland: soil temperature and evaporation in canopy and intercanopy patches, Int. J. Plant. Sci., 159, 1010-1017, 1998.

Brooks, P. D., McKnight, D., and Elder, K.: Carbon limitation of soil respiration under winter snowpacks: potential feedbacks between growing season and winter carbon fluxes, Global Change Biol., 11, 231-238, 2004.

Brown, S., and Lugo, A. E.: The storage and production of organic matter in tropical forests and their role in the global carbon cycle, Biotropica, 14: 161-187, 1982.

Cannell, M. G. R. and Dewar, R. C.: Carbon allocation in trees: a review of concepts for modeling, Adv. Ecol. Res., 25, 59-104, 1994.

Cairns, M. A., Brown, S., Helmer, E. H., and Baumgardner, G. A.: Root biomass allocation in the world's upland forests, Oecologia, 111, 1-11, 1997.

Cardinale, B. J., Srivastava, D. S., Duffy, J. E., Wright, J. P., Downing, A. L., Sankaran, M., and Jouseau, C.: Effects of biodiversity on the functioning of trophic groups and ecosystems, Nature, 443, 989-992, 2006.

Certini, G.: Effects of fire on properties of forest soils: a review, Oecologia, 143, 1-10, 2005.

Chapin III, F. S.: Effects of plant traits on ecosystem and regional processes: a conceptual framework for predicting the consequences of global change, Ann. Bot., 91, 455-463, 2003.

Chapin III, F. S., Shaver, G. R., Giblin, A. E., Nadelhoffer, K. J., and Laundre, J. A.: Responses of Arctic tundra to experimental 
and observed changes in climate, Ecology, 76, 694-711, 1995.

Chen, G. -S., Yang, Y. -S., Guo, J. -F., Xie, J. -S., and Yang, Z. -J.: Relationships between carbon allocation and partitioning of soil respiration across world mature forests, Plant Ecol., 212, 195206, 2010.

Clark, J. S., Dietze, M., Chakrabotry, S., Agarwai, P. K., Ibanez, I., LaDeau, S., and Wolosin, M.: Resolving the biodiversity paradox, Ecol. Lett., 10, 647-662, 2007.

Coley, P. D., and Barone J. A.: Herbivory and plant defenses in tropical forests, Annu. Rev. Ecol. Syst., 27, 305-335, 1996.

Comas, L. H., Bouma, T. J., and Eissenstat, D. M.: Linking root traits to potential growth rate in six temperate tree species, Oecologia, 132, 34-43, 2002.

Cornelissen, J., Aerts, R., Cerabolini, B., Werger, M., and van der Heijden, M.: Carbon cycling traits of plant species are linked with mycorrhizal strategy, Oecologia, 129, 611-619, 2001.

Cornwell, W. K., Cornelissen, J. H. C., Amatangelo, K., Dorrepaal, E., Eviner, V. T., Godoy, O., Hobbie, S. E., Hoorens, B., Kurokawa, H., Pérez-Harguindeguy, N., Quested, H. M., Santiago, L. S., Wardle, D. A., Wright, I. J., Aerts, R., Allison, S. D., Van Bodegom, P., Brovkin, V., Chatain, A., Callaghan, T. V., Díaz, S., Garnier, E., Gurvich, D. E., Kazakou, E., Klein, J. A., Read, J., Reich, P. B., Soudzilovskaia, N. A., Vaieretti, M. V., and Westoby, M.: Plant species traits are the predominant control on litter decomposition rates within biomes worldwide, Ecol. Lett., 11, 1065-1071, 2008.

Cox, P. M.: Description of the "TRIFFID" dynamic global vegetation model, Hadley Centre Technical Note no. 24, Met Office, Exeter, UK, available at: http://www.metoffice.gov.uk/ publications/HCTN/, last access: 23 February 2011, 2001.

Cramer, W., Bondeau, A., Woodward, F. I., Prentice, I. C., Betts, R. A., Brovkin, V., Cox, P. M., Fisher, V., Foley, J. A., Friend, A. D., Kucharik, C., Lomas, M. R., Ramankutty, N., Sitch, S., Smith, B., White, A., and Young-Molling, C.: Global response of terrestrial ecosystem structure and function to $\mathrm{CO}_{2}$ and climate change: results from six dynamic global vegetation models, Global Change Biol., 7, 357-373, 2001.

Craine, J. M., Wedin, D. A., and Reich, P. B.: The response of soil $\mathrm{CO}_{2}$ flux to changes in atmospheric $\mathrm{CO}_{2}$, nitrogen supply and plant diversity, Global Change Biol., 7, 947-953, 2001.

D'Antonio, C. M. and Vitousek, P. M.: Biological invasions by exotic grasses, the grass/fire cycle, and global change, Annu. Rev. Ecol. Syst., 23, 63-87, 1992.

Davidson, E. A.: Permafrost and wetland carbon stocks, Science, 330, 1176-1177, 2010

Davidson, E. A. and Janssens, I. A.: Temperature sensitivity of soil carbon decomposition and feedbacks to climate change, Nature, 440, 165-173, 2006.

de Araújo, A. C., Kruijt, B., Nobre, A. D., Dolman, A. J., Waterloo, M. J., Moors, E. J., and de Souza, J. S.: Nocturnal accumulation of $\mathrm{CO}_{2}$ underneath a tropical forest along a topographical gradient, Ecol. Appl., 18, 1406-1419, 2008.

de Boeck, H. J., Lemmens, C. M. H. M., Vicca, S., Van den Berge, J., Van Dongen, S., Janssens, I. A., Ceulemans, R., and Nijs, I.: How do climate warming and species richness affect $\mathrm{CO}_{2}$ fluxes in experimental grasslands?, New Phytol., 175, 512-522, 2007.

de Deyn, G. B., Cornelissen, H., and Bardgett, R. D.: Plant traits and soil carbon sequestration in contrasting biomes, Ecol. Lett., 11, 516-531, 2008.
Dias, A. T. C., van Ruijven, J., and Berendse, F.: Plant species richness regulates soil respiration through changes in productivity, Oecologia, 163, 805-813, 2010.

Diaz, S., Symstad, A. J., Chapin III, F. S., Wardle, D. A., and Huenneke, L. F.: Functional diversity revealed by removal experiments, TREE, 18, 140-146, 2003.

Diaz, S., Hodgson, J., Thompson, K., Cabido, M., Cornelissen, J., Jalili, A., Montserrat-Martí, G., Grime, J., Zarrinkamar, F., Asri, Y., Band, S., Basconcelo, S., Castro-Díez, P., Funes, G., Hamzehee, B., Khoshnevi, M., Pérez-Harguindeguy, N., PérezRontomé, M., Shirvany, F., Vendramini, F., Yazdani, S., AbbasAzimi, R., Bogaard, A., Boustani, S., Charles, M., Dehghan, M., de Torres-Espuny, L., Falczuk, V., Guerrero-Campo, J., Hynd, A., Jones, G., Kowsary, E., Kazemi-Saeed, F., Maestro-Martínez, M., Romo-Díez, A., Shaw, S., Siavash, B., Villar-Salvador, P., and Zak, M.: The plant traits that drive ecosystems: evidence from three continents, J. Veg. Sci., 15, 295-304, 2004.

Doren, R. F. and Whiteaker, L. D.: Effects of fire on different size individuals of Schinus terebinthifolius, Nat. Areas J., 10, 107113, 1990.

Fisher, J. B., Sitch, S., Malhi, Y., Fisher, R. A., Huntingford, C., and Tan, S.-Y.: Carbon cost of plant nitrogen acquisition: a mechanistic, globally applicable model of plant nitrogen uptake, retranslocation, and fixation, Global Biogeochem. Cy., 24, GB1014, doi:10.1029/2009GB003621, 2010.

Freschet, G. T., Cornelissen, J. H. C., Van Logtestijn, R. S. P., and Aerts, R.: Evidence of the "plant economics spectrum" in a subarctic flora, J. Ecol., 98, 362-373, 2010.

Friedlingstein, P., Cox, P., Betts, R., Bopp, L., von Bloh, W., Brovkin, V., Cadule, P., Doney, S., Eby, M., Fung, I., Bala, G., John, J., Jones, C., Joos, F., Kato, T., Kawamiya, M., Knorr, W., Lindsay, W., Matthews, H. D., Raddatz, T., Rayner, P., Reick, C., Roeckner, E., Schnitzler, K.- G., Schnur, R., Strassman, K., Weaver, A. J., Yoshikawa, C., and Zeng, N.: Climate-carbon cycle feedback analysis: results from the C4MIP model intercomparison, J. Climate, 19, 3337-3353, 2006.

Gao, F., Schaaf, C. B., Strahler, A. H., Roesch, A., Lucht, W., and Dickinson, R.: MODIS bidirectional reflectance distribution function and albedo climate modeling grid products and the variability of albedo for major global vegetation types, J. Geophys. Res., 110, D01104, doi:10.1029/2004JD005190, 2005.

Gartner, T. B. and Cardon, Z. G.: Decomposition dynamics in mixed-species leaf litter, Oikos, 104, 230-246, 2004.

Gaston, K. J.: Global patterns in biodiversity, Nature, 405, 220 $227,2000$.

Gill, R. A. and Jackson, R. B.: Global patterns of root turnover for terrestrial ecosystems, New Phytol., 147, 13-31, 2000.

Godbold, D. L., Hoosbeek, M. R., Lukac, M., Cotrufo, M. F., Janssens, I. A., Ceulemans, R., Polle, A., Velthorst, E. J., Scarascia-Mugnozza, G., de Angelis, P., Miglietta, F., and Peressotti, A.: Mycorrhizal hyphal turnover as a dominant process for carbon input into soil organic matter, Plant Soil, 281, 15-24, 2006.

González, G. and Seastedt, T. R. Soil fauna and plant litter decomposition in tropical and subalpine forests, Ecology, 82, 955-964, 2001.

Grime, J. P.: Vegetation classification by reference to strategies, Nature, 250, 26-31, 1974.

Grime, J. P.: Benefits of plant diversity to ecosystems: immediate, 
filter and founder effects, J. Ecol., 86, 902-910, 1998.

Grayston, S. J., Vaughan, D., and Jones, D.: Rhizosphere carbon flow in trees, in comparison with annual plants: the importance of root exudation and its impact on microbial activity and nutrient availability, Appl. Soil. Ecol., 5, 29-56, 1996.

Gruber, N. and Galloway, J. N.: An earth-system perspective of the global nitrogen cycle, Nature, 451, 293-296, 2008.

Harper, A. B., Denning, A. S., Baker, I. T., Branson, M. D., Prihodko, L., and Randall, D. A.: Role of deep soil moisture in modulating climate in the Amazon rainforest, Geophys. Res. Lett., 37, L05802, doi:10.1029/2009GL042302, 2010.

Hector, A., Beale, A., Minns, A., Otway, S., and Lawton, J. H.: Consequences of loss of plant diversity for litter decomposition: mechanisms of litter quality and microenvironment, Oikos, 90, 357-371, 2000.

Heilmeier, H., Erhard, M., and Schulze, E. -D.: Biomass Allocation and Water Use under Arid Conditions, in: Plant Resource Allocation, edited by: Bazzaz, F. A., and Grace, J., Academic Press, San Diego, 93 - 111, 1997.

Hillebrand, H.: On the generality of the latitudinal diversity gradient, Am. Nat., 163, 192-211, 2004.

Hobbie, E. A.: Carbon allocation to ectomycorrhizal fungi correlates with belowground allocation in culture studies, Ecology, 87, 563-569, 2006.

Holland, E. A., Braswell, B. H., Lamarque, J.-F., Townsend, A., Sulzman, J., Müller, J.-M., Dentener, F., Brasseur, G., Levy, H. I. I., Penner, J. E., and Roelofs, G.-J.: Variations in the predicted spatial distribution of atmospheric nitrogen distribution and their impact on carbon uptake by terrestrial ecosystems, J. Geophys. Res., 13, 15849-15866, 1997.

Hooper, D. U. and Vitousek, P. M.: Effects of plant composition and diversity on nutrient cycling, Ecol. Monogr., 68, 121-149, 1998.

Hooper, D. U., Chapin III, F. S., Ewel, J. J., Hector, A., Inchausti, P., Lavorel, S., Lawton, J. H., Lodge, D. M., Loreau, M., Naeem, S., Schmid, B., Setälä, H., Symstad, A. J., Vandermeer, J., and Wardle, D. A.: Effects of biodiversity on ecosystem function: a consensus of current knowledge, Ecol. Monogr., 75, 3-35, 2005.

Hughes, J. K., Hodge, A., Fitter, A. H., and Atkin, O. K.: Mycorrhizal respiration: implications for global scaling relationships, Trends Plant Sci., 13, 583-588, 2008.

Huston, M. A. and Wolverton, S.: The global distribution of net primary production: resolving the paradox, Ecol. Monogr., 79, 343-377, 2009.

Hättenschwiler, S. and Vitousek, P. M.: The role of polyphenols in terrestrial ecosystem nutrient cycling, Trends Ecol. Evol., 15, 238-243, 2000.

Hättenschwiler, S., Tiunov, A. V., and Scheu, S.: Biodiversity and litter decomposition in terrestrial ecosystems, Annu. Rev. Ecol. Evol. S., 36, 191-218, 2005.

Hättenschwiler, S., Aeschlimann, B., Coûteaux, M.-M., Roy, J., and Bonal, D.: High variation in foliage and litter chemistry among 45 tree species of a neotropical rainforest community, New Phytol., 179, 165-175, 2008.

Högberg, P., Nordgren, A., Buchmann, N., Taylor, A. F. S., Ekblad, A., Högberg, M. N., Nyberg, G., Ottosson-Löfvenius, M., and Read, D. J.: Large-scale forest girdling shows that current photosynthesis drives soil respiration, Nature, 411, 789-792, 2001.

Högberg, M. N., Briones, J. I., Keel, S. G., Metcalfe, D. B., Camp- bell, C., Midwood, A. J., Thornton, B., Hurry, V., Linder, S., Näsholm, T., and Högberg, P.: Quantification of effects of season and nitrogen supply on tree belowground carbon transfer to ectomycorrhizal fungi and other soil organisms in a boreal pine forest, New Phyt., 187, 485-493, 2010.

Inderjit and Weston, L.: Root exudates: an overview, in: Root Ecology, edited by: de Kroon, H. and Visser, E. J. W., SpringerVerlag, Heidelberg, 235-255, 2003.

Janssens, I. A., Lankreijer, H., Matteucci, G., Kowalski, A. S., Buchmann, N., Epron, D., Pilegaard, K., Kutsch, W., Longdoz, B., Grünwald, T., Montagnani, L., Dore, S., Rebmann, C., Moors, E. J., Grelle, A., Rannik, Ü., Morgenstern, K., Oltchev, S., Clement, R.,

Guðmundsson, J., Minerbi, S., Berbigier, P., Ibrom, A., Moncrieff, J., Aubinet, M., Bernhofer, C., Jensen, N. O., Vesala, T., Granier, A., Schulze, E.-D., Lindroth, A., Dolman, A. J., Jarvis, P. G., Ceulemans, R., and Valentini, R.: Productivity overshadows temperature in determining soil and ecosystem respiration across European forests, Global Change Biol., 7, 269-278, 2001.

Jonsson, M. and Wardle, D. A.: Context dependency of littermixing effects on decomposition and nutrient release across a long-term chronosequence, Oikos, 117, 1674-1682, 2008.

Johnson, D., Phoenix, G. K., and Grime, J. P.: Plant community composition, not diversity, regulates soil respiration in grasslands, Biology Lett., 4, 345-348, 2008.

Jurik, T. W., Briggs, G. M., and Gates, D. M.: Soil respiration of five aspen stands in Northern Lower Michigan, Am. Midl. Nat., 126, 68-75, 1991.

Keyes, M. R., and Grier, C. C.: Above- and belowground net production in 40-year-old Douglas-fir stands on low and high productivity sites, Can. J. For. Res., 11, 599-605, 1981.

Krinner, G., Viovy, N., de Noblet-Ducoudré, N., Ogée, J., Polcher, J., Friedlingstein, P., Ciais, P., Sitch, S., and Prentice, I. C.: A dynamic global vegetation model for studies of the coupled atmosphere-biosphere system, Global Biogeochem. Cy., 19, GB1015, doi:10.1029/2003GB002199, 2005.

Kurz, W. A., Dymond, C. C., Stinson, G., Rampley, G. J., Neilson, E. T., Carroll, A. A., Ebata, T., and Safranyik, L.: Mountain pine beetle and forest carbon feedback to climate change, Nature, 452, 987-990, 2008.

Kuzyakov, Y.: Sources of $\mathrm{CO}_{2}$ efflux from soil and review of partitioning methods, Soil Biol. Biochem., 38, 425-448, 2006.

Langley, J. A. and Hungate, B. A.: Mycorrhizal controls on belowground litter quality, Ecology, 84, 2302-2312, 2003.

Lerdau, M., and Gershenzon, J.: Allocation Theory and Chemical Defense, in: Plant Resource Allocation, edited by: Bazzaz, F. A., and Grace, J., Academic Press, San Diego, 265 - 277, 1997.

Levine, J. M. and D'Antonio, C. M.: Elton revisited: a review of evidence linking diversity and invasibility, Oikos, 87, 15-26, 1999.

Liao, C., Peng, R., Luo, Y., Zhou, Z., Wu, X., Fang, C., Chen, J., and Li, B.: Altered ecosystem carbon and nitrogen cycles by plant invasion: a meta-analysis, New Phyt., 177, 706-714, 2008.

Litton, C. M. and Giardina, C. P.: Below-ground carbon flux and partitioning: global patterns and response to temperature, Funct. Ecol., 22, 941-954, 2008.

Litton, C. M., Raich, J. W., and Ryan, M. G.: Carbon allocation in forest ecosystems, Global Change Biol., 13, 2089-2109, 2007.

Litton, C. M., Sandquist, D. R., and Cordell, S.: A nonnative invasive grass increases soil carbon flux in a Hawaiian tropical dry 
forest, Global Change Biol., 14, 726-739, 2008.

Luyssaert, S., Inglima, I., Jung, M., Richardson, A. D., Reichstein, M., Papale, D., Piao, S. L., Schulze, E.-D., Wingate, L., Matteucci, G., Aragao, L., Aubinet, M., Beer, C., Bernhofer, C., Black, K. G., Bonal, D., Bonnefond, J.-M., Chambers, J., Ciais, P., Cook, B., Davis, K. J., Dolman, A. J., Gielen, B., Goulden, M., Grace, J., Granier, A., Grelle, A., Griffis, T., Grünwald, T., Guidolotti, G., Hanson, P. J., Harding, R., Hollinger, D. Y., Hutyra, L. R., Kolari, P., Kruijt, B., Kutsch, W., Lagergren, F., Laurila, T., Law, B. E., Le Maire, G., Lindroth, A., Louteau, D., Malhi, Y., Mateus, J., Migliavacca, M., Misson, L., Montagnani, L., Moncrieff, J., Moors, E., Munger, J. W., Nikinmaa, E., Ollinger, S. V., Pita, G., Rebmann, C., Roupsard, O., Saigusa, N., Sanz, M. J., Seufert, G., Sierra, C., Smith, M.-L., Tang, J., Valentini, R., Vesala, T., and Janssens, I. A.: The $\mathrm{CO}_{2}$-balance of boreal, temperate and tropical forest derived from a global database, Global Change Biol., 13, 2509-2537, 2007.

Mack, M. C. and D'Antonio, C. M.: Impacts of biological invasions on disturbance regimes, TREE, 13, 195-198, 1998.

Marquard, E., Weigelt, A., Roscher, C., Gubsch, M., Lipowsky, A. and Schmid, B.: Positive biodiversity-productivity relationship due to increased plant density, J. Ecol., 97, 696-704, 2009.

Matson, P.: Plant-soil interactions in primary succession at Hawaii Volcanoes National Park, Oecologia, 85, 241-246, 1990.

McNaughton, S. J., Oesterheld, M., Frank, D. A., and Williams, K. J.: Ecosystem-level patterns of primary productivity and herbivory in terrestrial habitats, Nature, 341, 142-144, 1989.

Melillo, J. M., McGuire, A. D., Kicklighter, D. W., Moore III, B., Vorosmarty, C. J., and Schloss, A. L.: Global climate change and terrestrial net primary production, Nature, 363, 234-240, 1999.

Millenium Assessment: Ecosystems and Human Well-Being: Synthesis, Island Press, Washington DC, 2005.

Mittelbach, G. G., Steiner, C. F., Scheiner, S. M., Gross, K. L., Reynolds, H. L., Waide, R. B., Willig, M. R., Dodson, S. I., and Gough, L.: What is the observed relationship between species richness and productivity?, Ecology, 82, 2381-2396, 2001.

Moorcroft, P. R., Hurtt, G. C., and Pacala, S. W.: A method for scaling vegetation dynamics: the ecosystem demography model (ED), Ecol. Monogr., 71, 557-586, 2001.

Nadelhoffer, K. J., Aber, J. D., Melillo, J. M.: Fine roots, net primary production, and soil nitrogen availability: a new hypothesis, Ecology, 66: 1377-1390, 1985.

Neilson, R. P., Pitelka, L. F., Solomon, A. M., Nathan, R., Midgley, G. F., Fragoso, J. M. F., Lischke, H., and Thompson, K.: Forecasting regional to global plant migration in response to climate change, Bioscience, 55, 749-759, 2005.

Ohnson, K. R., Olson, R. J., Prince, S. D., Scurlock, J. M. O., and Zheng, D. L.: NPP multibiome: global primary production data initiative products, Oak Ridge National Laboratory Distributed Active Archive Center, Oak Ridge, Tennessee, USA, available at: http://daac.ornl.gov last access: 5 January 2011, 2001.

Oleson, K. W., Lawrence, D. M., Bonan, G. B., Flanner, M. G., Kluzek, E., Lawrence, P. J., Levis, S., Swenson, S. C., Thornton, P. E., Dai, A., Decker, M., and Dickinson, R.: Technical Description of version 4.0 of the Community Land Model (CLM), NCAR Technical Note, NCAR/TN-478+STR, NCAR, Boulder, 2010.

Ostle, N. J., Smith, P., Fisher, R., Woodward, F. I., Fisher, J. B., Smith, J. U., Galbraith, D., Levy, P., Meir, P., McNamara, N.
P., and Bardgett, R. D.: Integrating plant-soil interactions into global carbon cycle models, J. Ecol., 97, 851-863, 2009.

Pacala, S. W. and Tilman, D.: Limiting similarity in mechanistic and spatial models of plant competition in heterogeneous environments, Am. Nat., 143, 222-257, 1994.

Parton, W., Silver, W. L., Burke, I. C., Grassens, L., Harmon, M. E., Currie, W. S., King, J. Y., Adair, E. C., Brandt, L. A., Hart, S. C., and Fasth, B.: Global-scale similarities in nitrogen release patterns during long-term decomposition, Science, 315, 361-364, 2007.

Peltzer, D. A., Bellingham, P. J., Kurokawa, H., Walker, L. R., Wardle, D. A., and Yeates, G. W.: Punching above their weight: lowbiomass non-native plant species alter soil properties during primary succession, Oikos, 118, 1001-1014, 2009.

Peltzer, D. A., Allen, R. B., Lovett, G. M., Whitehead, D., and Wardle, D. A.: Effects of biological invasions on forest carbon sequestration, Global Change Biol., 16, 732-746, 2010.

Persson, J. and Näsholm, T.: Amino acid uptake: a widespread ability among boreal forest plants, Ecol. Lett., 4, 434-438, 2001.

Phillips, O. L., Martinez, R. V., Arroyo, L., Baker, T. R., Killeen, T., Lewis, S. L., Malhi, Y., Mendoza, A. M., Neill, D., Vargas, P. N., Alexiades, M., Cerón, C., Di Fiore, A., Erwin, T., Jardim, A., Palacios, W., Saldias, M., and Vinceti, B.: Increasing dominance of large lianas in Amazonian forests, Nature, 418, 770774, 2002.

Pierson, F. B. and Wight, J. R.: Variability of near-surface soil temperature on sagebrush rangeland, J. Range. Manage., 44, 491497, 1991.

Raich, J. W. and Potter, C. S.: Global patterns of carbon dioxide emissions from soils, Global Biogeochem. Cy., 9, 23-36, 1995.

Raich, J. W. and Schlesinger, W. H.: The global carbon dioxide flux in soil respiration and its relationship to vegetation and climate, Tellus, 44B, 81-99, 1992.

Raich, J. W. and Tufekcioglu, A.: Vegetation and soil respiration: correlations and controls, Biogeochemistry, 48, 71-90, 2000.

Reu, B., Proulx, R., Bohn, K., Dyke, J. G., Kleidon, A., Pavlick, R., and Schmidtlein S.: The role of climate and plant functional trade-offs in shaping global biome and biodiversity patterns. Global Ecol. Biogeogr., 20,570-581, 2010.

Richardson, D. M. and Rejmánek, M.: Conifers as invasive aliens: a global survey and predictive framework, Divers. Distrib., 10, 321-331, 2004.

Richardson, S. J., Allen, R. B., and Doherty, J. E.: Shifts in leaf N : $\mathrm{P}$ ratio during resorption reflect soil $\mathrm{P}$ in temperate rainforest, Funct. Ecol., 22, 738-745, 2008.

Ruess, R. W., van Cleve, K., Yarie, J., and Viereck, L. A.: Contributions of fine root production and turnover to the carbon and nitrogen cycling in taiga forests of the Alaskan interior, Can. J. Forest Res., 26, 1326-1336, 1996.

Rustad, L. E., Campbell, J. L., Marion, G. M., Norby, R. J., Mitchell, M. J., Hartley, A. E., Cornelissen, J. H. C., and Gurevitch, J.: A meta-analysis of the response of soil respiration, net nitrogen mineralization, and aboveground plant growth to experimental ecosystem warming, Oecologia, 126, 543-562, 2001.

Sage, R. F. and Kubien, D. S.: The temperature response of C3 and C4 photosynthesis, Plant Cell Environ., 30, 1086-1106, 2007.

Sato, H., Itoh, A., and Kohyama, T.: SEIB-DGVM: a new dynamic global vegetation model using a spatially explicit individualbased approach, Ecol. Model., 200, 279-307, 2007. 
Scheiter, S. and Higgins, S. I.: Impacts of climate change on the vegetation of Africa: an adaptive dynamic vegetation modelling approach, Global Change Biol., 15, 2224-2246, 2008

Sitch, S., Smith, B., Prentice, I. C., Arneth, A., Bondeau, A., Cramer, W., Kaplan, J. O., Levis, S., Lucht, W., Sykes, M. T., Thonicke, K., and Venevsky, S.: Evaluation of ecosystem dynamics, plant geography and terrestrial carbon cycling in the LPJ dynamic global vegetation model, Global Change Biol., 9, 161$185,2003$.

Silver, W. L. and Miya, R. Y.: Global patterns in root decomposition: comparisons of climate and litter quality effects, Oecologia, 129, 407-419, 2001.

Smith, B., Prentice, I. C., and Sykes, M. T.: Representation of vegetation dynamics in modeling of terrestrial ecosystems: comparing two contrasting approaches within European climate space, Global Ecol. Biogeogr., 10, 621-637, 2001.

Subke, J.-A., Inglima, I. and Francesca Cotrufo, M.: Trends and methodological impacts in soil $\mathrm{CO}_{2}$ efflux partitioning: A metaanalytical review, Global Change Biol., 12, 921-943, 2006.

Suding, K. N., Lavorel, S., Chapin, F. S., Cornelissen, J. H. C., D'ı az, S., Garnier, E., Goldberg, D., Hooper, D. U., Jackson, S. T., and Navas, M.-L.: Scaling environmental change through the community-level: a trait-based response-and-effect framework for plants, Global Change Biol., 14, 1125-1140, 2008.

Sykes, M. T. and Prentice, I. C.: Climate change, tree species distributions and forest dynamics: a case study in the mixed conifer/northern hardwoods zone of Northern Europe, Climatic Change, 34, 161-177, 1996.

Thornton, P. E., Lamarque, J.-F., Rosenbloom, N. A., and Mahowald, N. M.: Influence of carbon-nitrogen cycle coupling on land model response to $\mathrm{CO}_{2}$ fertilization and climate variability, Global Biogeochem. Cy., 21, GB4018, doi:10.1029/2006GB002868, 2007.

Tylianakis, J. M., Didham, R. K., Bascompte, J., and Wardle, D. A.: Global change and species interactions in terrestrial ecosystems, Ecol. Lett., 11, 1351-1363, 2008.

Vitousek, P. M., and Sanford, R. L. Jr.: Nutrient cycling in moist tropical forest, Annu. Rev. Ecol. Syst., 17, 137-167, 1986.

Vogt, K. A., Vogt, D. J., Brown, S., Tilley, J. P., Edmonds, R. L., Silver, W. L., and Siccama, T. G.: Dynamics of forest floor and soil organic matter accumulation in boreal, temperate, and tropical forests. In: Soil management and greenhouse effect, edited by: Lal, R., Kimble, J., Levine, E., and Stewart, B. A., Lewis Publishers, Boca Raton, 159-178, 1995.

Ward, S. E., Bardgett, R. D., McNamara, N. P., and Ostle, N. J.: Plant functional group identity influences short-term peatland ecosystem carbon flux: evidence from a plant removal experiment, Funct. Ecol., 23, 454-462, 2009.
Waring, R. H., and Schlesinger, W. H.: Forest ecosystems: concepts and management. Academic Press, Orlando, 1985.

Wardle, D. A. and Zackrisson, O.: Effects of species and functional group loss on island ecosystem properties, Nature, 435, 806-810, 2005.

Wardle, D. A., Bonner, K. I., Barker, G. M., Yeates, G. W., Nicholson, K. S., Bardgett, R. D., Watson, R. N., and Ghani, A.: Plant removals in perennial grassland: vegetation dynamics, decomposers, soil biodiversity, and ecosystem properties, Ecol. Monogr., 69, 535-568, 1999.

Wardle, D. A., Bardgett, R. D., Klironomos, J. N., Setälä, H., van der Putten, W. H., and Wall, D. H.: Ecological linkages between aboveground and belowground biota, Science, 304, 1629-1633, 2004.

Wardle, D. A., Wiser, S. K., Allen, R. B., Doherty, J. E., Bonner, K. I., and Williamson, W. M.: Aboveground and belowground effects of single-tree removals in New Zealand rain forest, Ecology, 89, 1232-1245, 2008.

Whittaker, R. H.: Communities and Ecosystems, MacMillan, New York, 1975.

Woodward, F. I. and Lomas, M. R.: Vegetation dynamicssimulating responses to climate change, Biol. Rev., 79, 643-670, 2004.

Wright, I. J., Reich, P. B., Westoby, M., Ackerly, D. D., Baruch, Z., Bongers, F., Cavender Bares, J., Chapin, F. S., Cornelissen, J. H. C., Diemer, M., Flexas, J., Garnier, E., Groom, P. K., Gulias, J., Hikosaka, K., Lamont, B. B., Lee, T., Lee, W., Lusk, C., Midgley, J. J., Navas, M.-L., Niinemets, Ü., Oleksyn, J., Osada, N., Poorter, H., Poot, P., Prior, L., Pyankov, V. I., Roumet, C., Thomas, S. C., Tjoelker, M. G., Veneklaas, E., and Villar, R.: The world-wide leaf economics spectrum, Nature, 428, 821-827, 2004.

Zaehle, S. and Friend, A. D.: Carbon and nitrogen cycle dynamics in the O-CN land surface model: 1 . Model description, site-scale evaluation, and sensitivity to parameter estimates, Global Biogeochem. Cy., 24, GB1005, doi:10.1029/2009GB003521, 2010.

Zak, D. R., Holmes, W. E., White, D. C., Peacock, A. D., and Tilman, D.: Plant diversity, soil microbial communities, and ecosystem function: are there any links?, Ecology, 84, 20422050, 2003.

Zelazowski, P., Malhi, Y., Huntingford, C., Sitch, S., and Fisher, J. B.: Changes in the potential distribution of humid tropical forests on a warmer world, Philos. T. R. Soc. A., 369, 137-160, 2011.

Zhang, D. Z., Hui, D., Luo, Y., and Zhou, G.: Rates of litter decomposition in terrestrial ecosystems: global patterns and controlling factors, J. Plant Ecol. UK, 1, 85-93, 2008. 